\title{
ANALYSIS OF PLATELET COUNT ON FIBROSIS DEGREE IN CHRONIC HEPATITIS B PATIENTS
}

\author{
Hairul Anwar, Mutmainnah, Ibrahim Abdul Samad \\ Department of Clinical Pathology,Faculty of Medicine, Hasanuddin University/Wahidin Sudirohusodo Hospital, Makassar, \\ Indonesia. E-mail: aroel_anwar144@yahoo.com
}

\begin{abstract}
Chronic hepatitis B is an infectious liver disease caused by hepatitis B virus that persist for more than 6 months. Fibrosis is a result of fibrogenesis which is the formation of connective tissue (scarring) caused by liver tissue damage. Liver damage will affect the production of thrombopoetin causing disturbances in the balance between destruction and production of platelet resulting in decreased platelet counts. This study was a retrospective cross-sectional study by taking the data from medical records of chronic hepatitis $B$ patients who were tested for complete blood count and fibroScan at the Dr.Wahidin Sudirohusodo Hospital Makassar from January 2014 to July 2016. The result showed a total of 323 chronic B hepatitis patients, 99 with severe fibrosis, 84 with moderate fibrosis and 140 with mild fibrosis. The Spearman correlation test showed a significant correlation between the platelet count and the degree of fibrosis $(p<0.001)$ and showed a positive correlation between both of them with a very strong correlation $(r=0.802)$. The Kruskal-Wallis test showed a significant difference between platelet count and the degree of fibrosis $(p<0.001)$. The conclusion is that a decreased platelet count is a sign of an increase in the degree of fibrosis in chronic hepatitis B patients. It is suggested to perform another study with larger samples based on the degree of fibrosis.
\end{abstract}

Key words: Platelet, degree of fibrosis, chronic hepatitis B

\section{INTRODUCTION}

Hepatitis $B$ is a liver disease caused by hepatitis $B$ virus infection. Hepatitis $B$ disease in its survival can cause inflammation and even damage to liver cells. Unfortunately, hepatitis sufferers do not feel or do not realize that they are infected by the virus since its typical complaint, flu-like complaint, does not develop immediately, or even cannot appear, so that people do not feel any complaints. Hepatitis B maybe acute or chronic (more than six months of survival) which later becomes liver cirrhosis and cancer. ${ }^{1-3}$

Chronic hepatitis B is a health problem in Asia. The incidence of chronic hepatitis B is at least $75 \%$ of 300 million people who have a persistently positive HBsAg. A third of the world's population even is known to have been exposed to the virus and about 600,000 people have died from acute or chronic hepatitis $B$ each year. The number of hepatitis $B$ patients in the healthy population in Indonesia is estimated to reach $4.0-20.3 \%$ with the number of patients outside Java Island higher than in Java Island. ${ }^{2,3}$

One of the liver disease complications is liver cirrhosis characterized by the disappearance of normal liver cells and the formation of connective tissue in the liver that is irreversible. The World Health Organization (WHO) provides histological limits on liver cirrhosis as a diffused process of liver disorder (almost uniform) characterized by the appearance of fibrosis and changes in the normal liver form into abnormal nodules. ${ }^{4}$

Fibrosis as a result of fibrogenesis is the process of formation of connective tissue (scar) due to damage of liver tissue. Liver fibrosis is one of the complications of chronic liver disease that can increase mortality rate. Determination of the degree of fibrosis can be a predictor of the mortality rate associated with chronic liver disease complications. ${ }^{5}$

FibroScan is a noninvasive method that is able to determine the stage of liver fibrosis more sensitively by measuring the mean of liver stiffness associated with fibrosis degree. The fibsroScan imaging technique can successfully determine the degree of liver fibrosis with a high degree of accuracy and also can replace liver biopsy as a gold standard. The instrument is more sensitive in determining the degree of liver fibrosis by measuring liver elasticity associated 
with the degree of fibrosis, divided into normal (F0): $<5 \mathrm{kPa}$; mild (F1): 5-9 kPa; moderate (F2-F3): 9.1$14.5 \mathrm{kPa}$; severe (F4):> $14.5 \mathrm{kPa} .{ }^{5,6}$ Nevertheless, this technique relatively is expensive and also difficult to set as one of the routine checks in several hospitals.

On the other hand, liver is also considered as the main site of production of thrombopoietin (TPO), a hormone associated with the maturation of megakaryocyte, metamegakaryocyte and platelet formations. Liver damage, as a result, will affect the formation of thrombopoetin (TPO), resulting in a disturbance of the balance between the amount of platelet production and the destruction of the liver, leading to decreased platelet count. A research con-
Installation of the Dr. Wahidin Sudirohusodo Hospital in Makassar. Samples of this research were taken from patients diagnosed with chronic hepatitis B by an internist in history through physical examination and investigation. Those patients had undergone routine blood tests at the FibroScan Laboratory and Examination Installation in the Gastroenterohepatology Subdivision of the Dr. Wahidin Sudirohusodo Hospital Makassar from January 2014 to July 2016. Next, data collected were statistically analyzed with Spearman correlation test and Kruskal-Wallis analysis test, with a $p$-value of $<0.05$ considered to be significant.

Table 1. Characteristics of the research samples

\begin{tabular}{|c|c|c|c|c|c|}
\hline Characteristics & Number of Patients & $\begin{array}{c}\text { Frequency } \\
(\%)\end{array}$ & Min & Max & Mean \pm SD \\
\hline Age (years) & 323 & 100 & 16 & 65 & $43.4 \pm 10.78$ \\
\hline \multicolumn{6}{|l|}{ Sex } \\
\hline Male & 218 & 67.49 & & & \\
\hline Female & 105 & 32.51 & & & \\
\hline Platelet Count $\left(10^{3}\right)$ & & & 27 & 352 & $204.29 \pm 80.4$ \\
\hline \multicolumn{6}{|l|}{ Degree of Fibrosis } \\
\hline Mild & 140 & 43.34 & & & \\
\hline Moderate & 84 & 26.01 & & & \\
\hline Severe & 99 & 30.65 & & & \\
\hline
\end{tabular}

Source: Secondary data

ducted by Juliana showed that there was a tendency of decreased serum thrombopoietin and thrombocyte concentrations when the degree of liver fibrosis is getting severe. In other words, this previous research indicated that thrombocytopenia in liver disease could not indicate the deficiency of thrombopoietin production. However, there is a correlation between liver disease and decreased expression of thrombopoietin receptor (c-Mpl) that may contribute to thrombocytopenia in liver disease. ${ }^{7,8}$

In Indonesia, the number of researches focused on thrombocyte count analysis associated with the degree of liver fibrosis is still small. Therefore, this research aimed to analyze the correlation of platelet count and liver fibrosis degree in chronic hepatitis $B$ patients by assessing the amount of platelets based on the degree of fibrosis in those patients.

\section{METHODS}

This research was conducted retrospectively with a cross-sectional approach by taking secondary data of chronic hepatitis B patients in the Medical Record

\section{RESULT AND DISCUSSION}

This research was conducted from January 2014 to July 2016. The number of samples was 323 data taken from the chronic hepatitis $B$ patients. Based on data, the average age of those patients was $43.4 \pm 10.78$ years-old. The number of male patients was known to be 218 (67.49\%), higher than the number of females, about 105 people (32.51\%). Besides, the data also showed that the average platelet count was $204.290 \pm 80.400$. The degree of fibrosis mostly found was mild one $(43.34 \%)$ as depicted in Table 1.

Results of Spearman correlation test revealed that there was a significant correlation between platelet count and degree of fibrosis in chronic hepatitis B patients $(p<0.001)$. The correlation of platelet count and fibrosis degree was known to be very strong and positive $(r=0.802)$ as illustrated in Table 2.

Moreover, results of the Kruskal-Wallis analysis showed that there was a significant difference between the platelet count and the fibrosis degree in chronic hepatitis B patients $(p<0.001)$ as shown in 
Table 3.

Table 2. Results of Spearman correlation analysis

\begin{tabular}{ll}
\hline & Degree of fibrosis \\
\hline Platelet count & $r=0.802$ \\
& $p<0.001$ \\
$n=323$ \\
\hline
\end{tabular}

Spearman correlation test

Table 3. Results of Kruskal-Wallis analysis

\begin{tabular}{llccc}
\hline & N & $\begin{array}{c}\text { Platelet count } \\
\left(\mathbf{1 0}^{\mathbf{3}}\right)\end{array}$ & p-value \\
\hline $\begin{array}{l}\text { Fibrosis } \\
\text { degree }\end{array}$ & Severe & 99 & $111(27-255)$ & $<0.01$ \\
& Moderate & 84 & $204(105-323)$ & \\
& Mild & 140 & $274.5(90-352)$ & \\
& & & & \\
\hline
\end{tabular}

Kruskal-Wallis analysis. Post hoc MannWhitney test: severe vs moderate, $\mathrm{p}<0.001$; severe vs mild, $p<0.001$; moderate vs mild, $p<0.001$. Data were presented in median (minimum-maximum).

Distribution of platelet count based on the degree of fibrosis in the chronic hepatitis $B$ patients

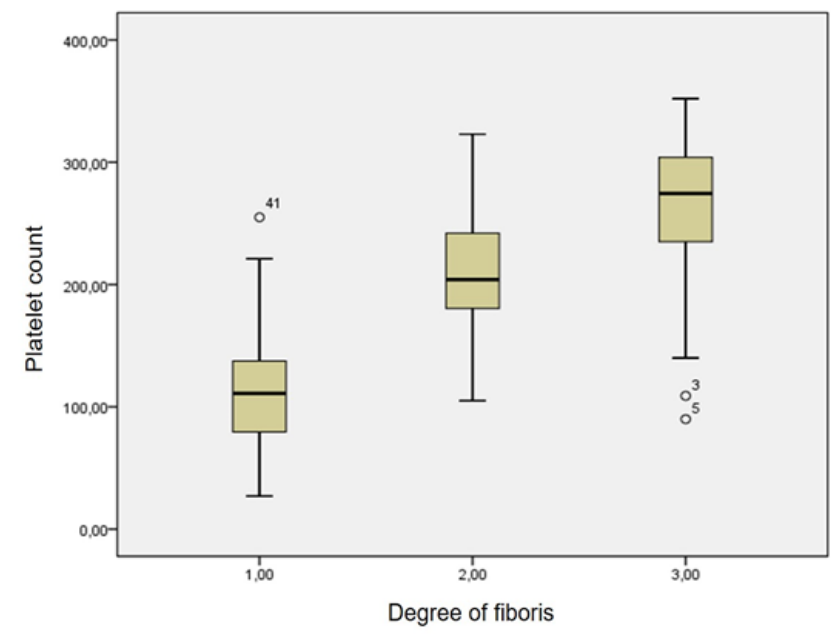

Figure 1. Distribution of platelet counts count based on the degree of fibrosis in the chronic hepatitis B patients

can be seen in Figure 1.

Based on the above data, the number of samples was 323 patients with the average age of $43.4 \pm 10.78$ years-old (16-65 years). The number of male patients was known to be 218 people (67.49\%), higher than the number of females, about 105 people (32.51\%). It indicates that males at an age range of 1665 years were more exposed to chronic hepatitis $B$ risk factors than females. Like the results of this research, a research conducted by Wahyuni showed that the incidence of chronic liver disease was more common in males than females at the age of 40-49 years. In other words, the productive ages were more exposed to risk factors for chronic liver disease, such as viral hepatitis as the most common cause of chronic liver disease. Similarly, Riskesdas in 2013 also revealed that hepatitis was more prevalent in males than females $(2-4: 1)$ and also more prevalent in the age group of $45-54$ years. ${ }^{5,9}$

Furthermore, the results of this research also found that there was a positive significant correlation between platelet count and fibrosis degree in chronic hepatitis B patients $(p<0.001$ and $r=0.802)$. It meants more severe degree of fibrosis, so the amount of platelets will be decreased. Similarly, a research conducted by Ceylan et al., showed that there was a significant difference between severe fibrosis and mild fibrosis. Increased platelet sequestration due to splenomegaly and decreased thrombopoietin production associated with liver cell failure were the main factors that causing thrombocytopenia. ${ }^{10}$

In addition, results of the Kruskal-Wallis analysis showed that there was a significant difference between platelet count and fibrosis degree in chronic hepatitis B patients ( $p$-value $<0.001$ ). Changes in platelet counts in various forms of liver disease, including those caused by hepatitis B virus, may explain how platelet count is considered as an indirect marker of liver fibrosis. Platelet is known to have a very close correlation with the liver since it is a source of thrombopoietin. Thrombocytopenia generally occurs in patients with acute liver injuries, such as acute liver failure, chronic hepatitis $B$ exacerbation and chronic liver failure. The degree of thrombocytopenia is associated with the progression of chronic liver disease. Many researches have shown that platelet count is one of the factors that reflects the extent of liver fibrosis or the severity of liver cirrhosis. ${ }^{11}$

Finally, based on the range, mean and median of platelet counts on mild, moderate and severe fibrosis degrees, it can be said that the more severe degree of fibrosis in chronic hepatitis B patients, so the amount of platelet will be decreased. Besides, determination of platelet count is considered as a relatively simple laboratory procedure. Thus, platelet count is expected to be useful in the follow-up of chronic hepatitis B patients, especially in health services that still have do 
not modern supporting facilities (more complete 6 . laboratory parameters, liver biopsy, and fibroScans).

\section{CONCLUSION AND SUGGESTION}

In conclusion, a decline in platelet counts could be considered as a sign of increased degree of liver fibrosis in chronic hepatitis B patients. Nevertheless, further researches are recommended to have more samples based on the degree of fibrosis.

\section{REFERENCES}

1. Sulaiman AS. Pendekatan Terkini Hepatitis B dan C dalam Praktik Klinis Sehari-hari, Jakarta, Sagung Seto, 2010; 1-16.

2. PPHI, Hepatitis B, diakses dari http://pphi-online.org diakses pada 5 juli 2015.

3. Soemohardjo S, Gunawan S. Hepatitis B Kronis dalam IImu Penyakit Dalam, Ed ke-6., Jilid II, Jakarta, Interna publishing, 2014; 1963-1971.

4. PPHI, Sirosis Hati, diakses dari http://pphi-online.org, diakses pada 5 juli 2015.

5. Soleh D, Arianton, Siswandari. Hubungan APRI terhadap derajat fibrosis pasien penyakit hati kronis. Mandala of Health. 2011; 5(2): 1-7.
6. Macías J, Camacho A, Von Wichmann MA, Lopes Cortes $L F$, Ortega $E$, et al. Prediction of survival and decompensations of cirrhosis among HIV/HCV-co-infected patients: a comparison of liver stiffness versus liver biopsy. $7^{\text {th }}$ IAS Conference on HIV Pathogenesis, Treatment and Prevention, Kuala Lumpur, World J Gastroenterol, 2013; 18: 2784-2792.

7. Juliana IM dan Wibawa DN. Korelasi antara derajat penyakit sirosis hati berdasarkan klasifikasi Child-TurcottePugh dengan konsentrasi trombopoietin serum, Jurnal Penyakit Dalam, 2008; 9(1): 23-35.

8. Tambunan KL. Gangguan Hemostasis Pada Sirosis Hati dalam Buku Ajar Ilmu Penyakit Hati, Ed I., Jakarta, Jayabadi, 2007; 421-427.

9. Hadi S. Hepatitis Kronis dalam: Gastroenterologi. Ed Ketujuh., Bandung, Penerbit PT Alumni, 2002; 583-607.

10. Fauzi Achmad. EPIDEMI-Prevalensi Penyakit Hepatitis Kronis di Indonesia. Available at: http:// www.depkes.go.id. Februari 2011.

11. Karasu Z, Tekin F, Ersoz G, Gunsar F, Batur Y, et al. Liver Fibrosis is associated with decreased peripheral platelet count in patients with chronic hepatitis B and C. PubMed, 2007; 52(6): 1535-1539.

12. Nwokediuko SC. Quantitative platelet abnomalities in patients with hepatitis B virus-related liver disease, $\mathrm{Ni}$ geria, Gastroenterol Res and Elmer Press, 2009; 344349. 